\title{
ENTEOGENI: PSIHOAKTIVNI SASTOJCI NEKIH RITUALA I NJIHOVA SUDBINA
}

Pregledni rad

Primljeno: 1. 9. 2017.

Prihvaćeno: 24. 10. 2017.

DOI: $10.15176 /$ vol54no205

UDK 316.723

613.83: 39

\section{GORAN GOLDBERGER}

Zagreb

Članak se bavi fenomenom upotrebe psihoaktivnih supstanci u nekim ritualima. Uz problem definicije droga i srodnih pojmova (psihodelici, halucinogeni, enteogeni), opisuju se mape izmijenjenih stanja svijesti povezanih s njihovom upotrebom, tipovi psihodeličnog iskustva i faktori koji utječu na njih, zatim pojmovi religije/vjere i rituala/ obreda, kojima se određuje pojmovni okvir, te neadekvatno razmatranje tog fenomena u kontekstu Hrvatske. Objašnjava se povijesni i suvremeni kontekst njihove upotrebe u liječenju, šamanizmu, magiji, religiji, ali i duhovnosti, umjetnosti, psihijatriji, psihoterapiji, kontrakulturi i supkulturi mladih. Predstavlja se geografija, botanički i kulturni opseg njihovog korištenja, sličnosti i razlike u njihovoj upotrebi i u odgovorima društvenih institucija. Naglašavaju se posljedice i problemi prouzročeni regulacijom upotrebe psihoaktivnih supstanci u suvremenom društvu, poput restriktivnog zakonodavstva, "rata protiv droga", onemogućavanja znanstvenog istraživanja tog fenomena, ali i kršenja ljudskih prava i vjerskih sloboda. U zaključku rada naznačen je istraživački potencijal ove teme i izazova koje ona nudi.

Ključne riječi: enteogeni, psihoaktivne supstance, religija, duhovnost, kontrakultura, supkultura, ritual, društvena regulacija

\section{UVOD: MAPA PODRUČJA, POJMOVA I ISKUSTVA}

Neki fenomeni u "uobičajenoj stvarnosti” utječu na razmatranje zatečenog stanja i postojećih obrazaca percepcije, djelovanja i življenja, a mogu biti i dio procesa uključivanja pojedinaca i skupina u šire društvo ili pak njihovog isključivanja. "Neuobičajena stvarnost" (Castaneda 1979) i "ekstaza" (Elijade 1990) izazvana upotrebom psihoaktivnih supstanci u suvremenim društvima svakako je fenomen koji pobuđuje takva pitanja, javne rasprave i sukobe.

Neuobičajena stanja svijesti prihvaćaju mnoga društva i kulture. No, dok prihvaćaju i institucionaliziraju neka stanja svijesti, druga zabranjuju te se razlikuju u broju stanja koja 
vrednuju. Većina njih je polifazna i primaju znanje i poglede na svijet od dodatnih modaliteta svijesti, uključujući upotrebu psihodelika. Zapadna je kultura relativno jednofazna, kognicentrična, privilegira "uobičajenu budnu svjesnost” (Walsh i Grob 2006) i prihvaća uglavnom intoksikaciju kofeinom, alkoholom i duhanom (Boyd 2001).

Prema Weilu i Rosenu (1983), čini se da je potreba za povremenom promjenom stanja svijesti dio ljudske prirode, prisutna je u različitim kulturama, razdobljima i prostorima, a uz navedeni primjer upotrebe psihoaktivnih sredstava, takva stanja ljudi dostižu i odlaskom u prirodu, sviranjem i slušanjem glazbe, plesom, meditacijom, molitvom, sudjelovanjem u religijskom ritualu i drugim aktivnostima. ${ }^{1}$ Ta je želja, prema de Feliceu, intrinzično povezana s potragom za transcendencijom kao jednim od najosnovnijih ljudskih instinkta (Shannon 2008: 52).

Štoviše, čini se da neki oblik te potrebe pokazuju i određene životinje. I one koriste psihoaktivne biljke (Ott 1993: 32). Samorini (2002) naglašava slučajeve u kojima ljudi utječu na životinje i njihovu upotrebu psihoaktivnih biljaka, dok kod životinja u divljini nema takvog utjecaja i one to ne rade samo slučajno nego i namjerno. On predstavlja brojne primjere, među ostalim, mački, konja, krava, ježeva, vjeverica, slonova, čimpanzi, babuna, gorila, sobova, karibua, nekih ptica i insekata, koji koriste mačju travu, ludu travu, kofein, alkohol, marihuanu i njene sjemenke, ibogain, muharu i druge psihoaktivne biljke. Intoksikacija i izmjena stanja svijesti pomažu prilagodbi i razvoju životinja i ljudi, promjeni njihovih inače krutih shema i obrazaca, te razvoju novih i korisnih načina razmišljanja i djelovanja (Samorini 2002).

U literaturi se javljaju problemi definicije i određenja pojma droga uobičajeno zasnovanih na službenim definicijama arbitrarno određenim od strane utjecajnih i dominantnih državnih i međunarodnih institucija, te podjele i klasifikacije droga ${ }^{2}$ zasnovane na fiksnim učincima i farmakološkim svojstvima, a bez pomnijeg razmatranja varijabilnosti djelovanja (Dubreta 2005) i konteksta ili namjere upotrebe. ${ }^{3}$

1 Prema Barušsu (2003), izmijenjena stanja svijesti uključuju maštanje, spavanje i snove, hipnozu, trans, transcendenciju, te iskustva povezana sa smrću i psihodelicima. Ona su, prema Charlesu T. Tartu, "kvalitativne promjene u cjelokupnom obrascu mentalnog funkcioniranja, tako da osoba koja ih doživljava osjeća da se njena svijest radikalno razlikuje od načina na koji uobičajeno funkcionira" (Barušs 2003: 8). Prethodno navedeni primjeri ukazuju i na jednu razliku između tih stanja: dok na stanja izazvana spavanjem i snovima čovjek nema direktni utjecaj, u ostalim je primjerima prisutan njegov direktni utjecaj i mogućnost slobodnog izbora.

2 Prema jednoj od najčešće citiranih podjela droga, onoj Svjetske zdravstvene organizacije, droge se dijele na depresore (opijum i njegovi derivati), stimulanse (kokain, amfetamin) i halucinogene (LSD, marihuana) (Dubreta 2005: 15). Većina halucinogena dolazi iz biljnog svijeta, neki su iz životinjskog (žabe krastače, žabe, ribe), a postoji i sintetička skupina (LSD, TMA, DOB) (Schultes, Hofmann i Rätsch 2002: 14). U biljnom svijetu, THC dolazi iz konoplje, meskalin iz kaktusa pejotl i San Pedro, LSD iz ergotamina i drugih ergot alkaloida koji su u ergotu (gljivica na raži), psilocibin iz gljive Psilociba, DMT (uz prisutnost MAO inhibitora) iz ajahuaske (kombinacija lijane Banisteriopsis caapi i grma Psychotria viridis), ibogain iz biljke Tabernanthe iboga, muscimol iz gljive muhare, a skopolamin iz tatule i mandragore (Grinspoon i Bakalar 1979; Schultes, Hofmann i Rätsch 2002).

3 Antropologinja Blätter naznačuje osnovne svrhe korištenja droga: 1) hedonistička/rekreativna, 2) kompenzacijska/sigurnosni ventil, 3) stvaranje identiteta/grupna kohezija, 4) religijska, 5) zdravstvena, 6) ekonomska, te 7) politička (Barker 2005: 182). 
U literaturi vezanoj uz upotrebu psihoaktivnih sredstava ${ }^{4}$ koriste se brojni pojmovi. Oni su većinom oblikovani kao ideološko oružje tijekom političko-kulturnog ratovanja 1960-ih u SAD-u i drugdje (Grinspoon i Bakalar 1979). Njihova raznolikost očituje se u terminima psihotomimetici (izazivaju psihozu), halucinogeni (proizvode halucinacije), psihodisleptici (iskrivljavaju ili remete um), fantastici, oneirogenici (izazivaju snove), psiholitici (opuštaju um), psihodelici (očituju um ili dušu) (Grinspoon i Bakalar 1979), iluzionogenici (izobličuju uobičajenu percepciju okoline) ili psihotropici (izmjenjuju um ili misli) (Barušs 2003).

Ipak, najčešći su pojmovi halucinogeni, psihodelici, a u zadnje vrijeme i enteogeni. Halucinogeni su, prema Hofferu i Osmondu, "kemikalije koje u netoksičnim dozama proizvode promjene u percepciji, mislima i raspoloženju, a rijetko mentalnu konfuziju, gubitak pamćenja ili dezorijentaciju za osobu, mjesto i vrijeme" (Schultes, Hofmann i Rätsch 2002: 13). Pojam psihodelici odnosi se na droge "koje bez uzrokovanja fizičke ovisnosti, žudnje, glavnih fizioloških poremećaja, delirija, dezorijentiranosti ili amnezije, više ili manje pouzdano stvaraju misli, raspoloženja i uočljive promjene inače rijetko doživljavane, osim u snovima, kontemplativnoj i vjerskoj zanesenosti, bljeskovima živopisne nesvjesne memorije, te akutnoj psihozi" (Grinspoon i Bakalar 1979: 9).

Međutim, termin psihodelik zasićen je značenjima psihodelične revolucije 1960-ih, halucinogen naglašava značaj halucinacija, a oba pojma su sinonimi za delirij, ludost ili psihozu. Stoga je skovan pojam enteogen da striktnije naglasi religijski kontekst upotrebe psihoaktivnih supstanci. Entheos (na grčkom: "unutarnje božansko") i korijen gen (na grčkom: akcija "postajanja") opisuje stanje čovjeka inspiriranog ili zaposjednutog bogom koji mu ulazi u tijelo tijekom proročkih napada, erotske strasti, umjetničkog stvaralaštva i religijskih ceremonija u kojima se doživljavaju mistička iskustva korištenjem supstanci povezanih s božanstvom. U tom kontekstu, on se odnosi na "biljke koje proizvode vizije i koje su korištene u šamanskim i religijskim ceremonijama ili, u malo širem smislu, i druge droge, prirodne i umjetne, koje induciraju izmjenu svijesti sličnu onima dokumentiranim za ritualno gutanje tradicionalnih enteogena" (Ruck i dr. 1979: 145-146). U nastavku rada ovi se pojmovi koriste naizmjenično, a najviše psihoaktivna sredstva i enteogeni.

Prirodu djelovanja tih sredstava pokazuju tipovi psihodeličnog iskustva koji nisu međusobno isključivi, nego su višeslojni. Prema Walteru Pahnkeu, ima ih pet: 1) psihotični (jako intenzivno i negativno, strah, paranoja, nelagoda, konfuzija, depresija, izolacija); 2) psihodinamski (izranjanje nesvjesnih elemenata u svijesti); 3) kognitivni (izrazito lucidne misli, nove perspektive, logično, kreativno); 4) estetski (intenzivna izmjena osjeta i percepcije, sinestezija); i 5) transcendentalni/mistički (jedinstvo sa svime, nadilaženje vremena i prostora, duboke pozitivne emocije, osjećaj svetosti, noetička kvaliteta prosvjetljenja, paradoksičnost, neizrecivost, prolaznost, trajne pozitivne promjene u stavovima i ponašanju) (Pahnke 1967).

${ }^{4}$ Dobar izvor referenci te pregled multidisciplinarnosti i širine područja nude sljedeće knjige i zbornici: Aaronson i Osmond (1970); Forte (1997); Furst (1972); Grinspoon i Bakalar (1979); Lyttle (1999); Ott (1993); Roberts (2001); Walsh i Grob (2005). 
Stanislav Grof razlikuje četiri tipa psihodeličnog iskustva: 1) apstraktni i estetički (vizije, površno iskustvo); 2) psihodinamski (freudovska razina materijala psihoanalize u direktnom ponovno proživljenom ili simboličkom obliku, struktura nesvjesne memorije povezuje se s nekom pojedinačno jakom emocijom ili događajem, a izaziva i dobnu regresiju); 3) perinatalni (trauma rođenja, bolesti i smrti, prolazi se kroz četiri stadija osnovnih perinatalnih matrica); i 4) transpersonalni (obuhvaća Jungovo kolektivno nesvjesno, reinkarnacijske fenomene, mističnu ekstazu i druga iskustva u kojima se čini da um transcendira granice individualne osobe ili ograničenja vremena i prostora, gubljenje identiteta i preuzimanje tuđeg) (Grinspoon i Bakalar 1979).

Karakteristike iskustava s psihodelicima uključuju sljedeće: 1) usporavanje vremena i koncentraciju na sadašnjost, uz opadanje kompulzivne brige za budućnost; 2) svijest o oprečnosti - shvaćanje da su stanja, stvari i događaji koje obično nazivamo suprotstavljenima nezavisni, odnosno viđenje da su eksplicitno različite stvari implicitno iste, što stvara osjećaj čuđenja i može generirati konfuziju, paranoju i stravu; 3) svijest o relativnosti - viđenje osobe da je ona dio beskrajne hijerarhije procesa i bića u kojoj svaka razina u suštini sadrži istu situaciju (sva bića su jedno biće radeći istu stvar na što je više moguće različitih načina); i 4) svijest o beskonačnoj energiji (često $u$ obliku intenzivnog bijelog svjetla) - viđenje da je sva egzistencija jedna energija i da je ta energija naše vlastito biće (Watts 1968).

Tri faktora koji imaju najveći utjecaj na psihodelična iskustva korisnika su 1) droga/doza, odnosno količina, 2) set ili dugoročne značajke osobnosti i trenutna očekivanja pojedinca od iskustva uzimanja droge, te 3) setting ili okruženje, odnosno fizički, kulturni i društveni okoliš u kojem se droga koristi (lokacija, drugi ljudi, objekti, kulturni stavovi i vjerovanja o tim iskustvima) (Barker 2005; Smith 1964).

Fenomen upotrebe psihoaktivnih sredstava u sebi sadrži svjetovne i sakralne elemente, a pojavljuju se i pojmovi religije/vjere i rituala/obreda koje je potrebno definirati i razlikovati, što će odrediti pojmovni okvir ovog rada.

Prema Općem religijskom leksikonu, religija je "sustav vjerovanja, etičkih vrijednosti i čina kojima čovjek izražava svoj odnos prema svetomu" i on može biti subjektivan (religioznost očitovana u osobnom štovanju i klanjanju) i objektivan (religijska ustanova ga objektivira u riječi (obrascima molitvi, vjeroispovijedima, dogmama), gesti (obredima), predmetu (sakralnim predmetima i objektima) i religijskoj zajednici) (Rebić 2002: 798). S njom je blisko povezan i pojam vjere, a on je "temeljni stav kojim se u intimi vlastite savjesti prihvaća sveto ili vjerske istine neke religije" (isto: 1015).

I pojam rituala/obreda se donekle odnosi na sakralno okruženje i sveto. U obredu se nalaze "ustaljene geste, čini i verbalni obrasci kojima čovjek izražava svoj odnos prema svetome" i on označava "sustav obreda uobičajen u nekoj religijskoj zajednici ili crkvi" (isto: 651). Također, pojavljuje se i pojam inicijacijski obred za "obred kojim se inicijant uvodi u neku religijsku zajednicu ili tajno bratstvo", a koji igra važnu ulogu u humanizaciji i socijalizaciji ljudskih bića i sastavljen je od tri dijela: simboličnog raskida s nekadašnjim 
stanjem ili ulogom, izdvajanja iz nekadašnje sredine, te uvođenja u novu sredinu s novom ulogom $^{5}$ (isto: 362). Na kraju, pojavljuje se i bliski pojam obredi prijelaza, a odnosi se na ceremonije koje se povezuju s prijelazima unutar životnog ciklusa, koji su bili izraženiji $u$ tradicionalnim nego u industrijskim društvima (Abercrombie, Hill i Turner 2008: 243). Prema van Grennepu, to su "obredi koji prate svaku promjenu mjesta, stanja, društvenog položaja i dobi” (lolar 2013).

Razmatranje ovih pojmovnih objašnjenja pokazuje da je za temu ovog rada najkorisniji pojam rituala, koji uključuje "svako formalno djelovanje prema ustaljenom obrascu koje preko simbola izražava općeprihvaćeno ili zajedničko značenje” (Abercrombie, Hill i Turner 2008: 317), a i raznolike oblike religijskih i društvenih inicijacija i obreda prijelaza u kojima se koriste psihoaktivna sredstva. Stoga će se u nastavku osim pojma psihoaktivna sredstva koristiti i pojam ritual.

\section{HRVATSKI KONTEKST}

Upotreba enteogena i drugih psihoaktivnih sredstava u ritualima relativno je slabo istražena pojava u hrvatskom kontekstu. Milićević Bradač (2002) razmatra njihovu upotrebu u povijesnom kontekstu "Vučedolske golubice" kao posude. Lokalitet nalaska uključuje tri elementa (pticu, jelena i metalurgiju) povezana s glavnom odlikom šamanske tehnike ekstatičkog putovanja. Autorica smatra da je posuda sadržavala halucinogeno piće za šamanske rituale, razmatra o kojem bi piću mogla biti riječ i zaključuje da je svaka od navedenih tvari mogla biti dostupna "vučedolskim znalcima", ali da je vjerojatno "njihovo piće bilo pivo, medovina, alkohol od jabuka ili od brezova soka", a ono što ga je činilo moćnim "su biljni dodaci ili gljive i gljivice" (Milićević Bradač 2002: 94). Ostaci spoznaja o svojstvima svetih gljiva na području bivše Jugoslavije mogu se razaznati kroz rečenicu "Najeo se ljutih gljiva” (Wasson i dr. 1986: 71), koja se koristi u opisu “čudnog” stanja nekog pojedinca ili nerazumijevanja onoga što netko čini.

U suvremenom kontekstu razmatra se u literaturi o duhovnosti New Agea (Grakalić 1994), supkulturama mladih (Krnić i Perasović 2013; Perasović 2001), konzumentima marihuane (Dubreta 2005), rastafarijancima (Dubreta i Perasović 1990; Perasović 2007), etnobotaničarskim značajkama bilja i njihovoj upotrebi u šamanskim i religijskim obredima (Keller 2010), u tematskom bloku časopisa Zarez o psihodelicima u duhovnosti i medicini (Roško 2005), te u svojevrsnom putopisu o drogama i stavovima aktera o njima u svijetu (Plečko 1997). Osim spomenutih radova, prema trenutnim saznanjima autora, u Hrvatskoj ne postoje druga istraživanja o upotrebi psihoaktivnih sredstava u ritualnoj praksi. No u

${ }^{5}$ Tri navedena dijela incijacijskih obreda predstavio je francuski etnograf Arnold van Gennep u svojoj knjizi Obredi prijelaza iz 1909. godine. On napominje da se njihova struktura sastoji od tri faze: separacije (osoba izlazi iz trenutnog statusa), tranzicije (kratki interval bezvremenosti i socijalne nestrukturiranosti) i reagregacije (osoba ulazi u novu fazu života ili socijalni status) (lolar 2013). 
Hrvatskoj se enteogeni ipak koriste, ali uglavnom u tajnosti zbog konteksta ilegalnosti takvih supstanci.

Jedan javni i negativan primjer dogodio se u Hrvatskoj 2009. godine, u kontekstu recesije i krize vlasti HDZ-ove koalicije, koja se u javnosti često smatra konzervativnom i bliskom Katoličkoj crkvi. Nova godina počela je s novinskim naslovima o lokalnom šamanu, članu HDZ-a i načelniku općine Saborsko, Luki Hodaku. On je dao legalnu halucinogenu biljku buniku u tekućem obliku četvorici muškaraca koji su sudjelovali u ritualu s bubnjevima na njegovom imanju tijekom novogodišnje proslave. Rezultat tog događaja je smrt jednog od prijatelja i susjeda koji ju je koristio te je legao pored vatre i izgorio. Policija je sve preživjele sudionike odvela u psihijatrijsku bolnicu na oporavak, nakon čega su pušteni. Gradonačelnik je ponudio ostavku na svoju dužnost, ali je, prema informacijama objavljenim u novinama, nastavio sa svojim načelničkim i šamanskim praksama, te je tvrdio da će patentirati svoj iscjeliteljski tekući lijek. HDZ je svojeg člana proglasio nepoželjnim, maknuo ga s izbornih lista i izbacio iz stranke ("Luka Hodak u Saborskom..." 2009; Ma. 2009), a i Katolička crkva je najavila da će ga izopćiti ("I Crkva i HDZ..." 2009). Bila je podignuta i optužnica pred Općinskim državnim odvjetništvom u Ogulinu jer je počinio teško kazneno djelo protiv opće sigurnosti, te je 2010. proglašen krivim za držanje i pripremanje napitka od bunike koji je otrovao i ubio njegova prijatelja. Nepravomoćno je osuđen na dvije godine zatvora uz rok kušnje od pet godina (Tuškan 2010).

Kroz istraživački interes za fenomen ritualne upotrebe enteogena, autor ovog rada upoznao je neke od aktera te scene u Hrvatskoj, s kojima je razgovarao i dogovorio sudjelovanje u trima različitim ceremonijama, u kojima je koristio kvalitativnu metodu promatranja. Tako je otkrio prisutnost šamanskih rituala u kojima se koriste enteogeni poput kaktusa San Pedro i pejotl, duhana, ajahuaske i sekreta amazonske kambo žabe tijekom posjeta šamana iz Južne Amerike Hrvatskoj. Poziv lokalnog organizatora ceremonije - na osnovi prijateljske preporuke - uključuje informacije o šamanu, ritualu, mjestu i datumu njegova odvijanja, te pripremi uoči rituala (namjera, prehrana koja se koristi tjedan dana i detoksicira organizam). Sam višesatni ritual - nakon odluke, dolaska, okupljanja i upoznavanja sudionika i šamana - uključuje uređivanje i posvetu prostora, oltara i enteogena, dijeljenje i konzumaciju uz pjevanje i sviranje ikarosa (pjesme i molitve posvećene duhu supstance da podrži namjere sudionika), istovremenu intoksikaciju, detoksikaciju i čišćenje tijela (dogodi se i da sudionici povraćaju), te završetak uz zajedničku završnu molitvu, zahvalu i objed, a često i kasniju osobnu interpretaciju i integraciju doživljaja. Isto tako, pojedinci iz Hrvatske odlaze u Južnu Ameriku istraživati, doživjeti, učiti i/ili inicirati se u šamanske prakse. O takvim temama i iskustvima raspravljaju i časopisi Nexus i Svjetlost koje objavljuje nakladnička kuća Teledisk, uz knjige koje se odnose na ovu tematiku.

Ujedno postoje i harm reduction udruge koje se zalažu za smanjenje društvene štete pružanjem točnih informacija o korištenju, djelovanju i miješanju psihoaktivnih supstanci, koje se koriste bez obzira na zabrane, što doprinosi sprječavanju potencijalnih problema koji proizlaze iz njihove upotrebe. Takvim djelovanjem udruga za zdraviju supkulturnu scenu Špica prikupila je i podatke za knjigu o hrvatskoj party sceni (Krnić i Perasović 
2013). Prema podacima Udruge heroinskih ovisnika (www.uho.hr) neki hrvatski ovisnici odlazili su u Sloveniju na ceremoniju ibogaina u vjersku zajednicu Sakrament Prehoda (http://sacrament.kibla.si).

Današnje komunikacijske tehnologije i internetske mreže poput Facebooka ili Twittera omogućavaju lakšu dostupnost informacija i komunikacije, koja rezultira istraživanjem i spomenutim slučajevima susreta hrvatskih građana sa psihoaktivnim supstancama. $\mathrm{Ti}$ susreti nameću potrebu prikaza istraživanja upotrebe psihoaktivnih sredstava u različitim ritualnim praksama. Hrvatska znanstvena zajednica, u većoj mjeri iz područja društvenih znanosti i sociologije, zanemarila je tu temu. Namjera rada je da pruži poticaj istraživanju tog fenomena u Hrvatskoj, kao i njegovog zdravstvenog, terapijskog, duhovnog i religijskog potencijala, te sprječavanju negativnih učinaka i zloupotrebe. Također, ovaj rad problematizira povijesni i suvremeni kontekst upotrebe psihoaktivnih sredstava, odnos društvenih institucija prema njima, regulaciju njihove upotrebe, probleme restriktivnog zakonodavstva i rata protiv droga koji doprinose zanemarivanju znanstvenog istraživanja tog fenomena, ali i kršenju ljudskih prava i vjerskih sloboda.

\section{POVIJESNI KONTEKST UPOTREBE PSIHOAKTIVNIH SREDSTAVA}

Pretpovijesni ljudi dobro su istražili svu vegetaciju koju su htjeli koristiti kao potencijalni izvor hrane, lijeka, enteogena, oružja ili goriva (Dannaway 2010: 485). Ljudska upotreba psihoaktivnih sredstava prethistorijski je fenomen, vjerojatno iz pleistocena, a arheološki i povijesni dokazi ukazuju na to da ih se u okviru kultura koristi barem 10000 godina (Merlin 2003). U Europi je prisutan sofisticirani pretkršćanski kulturni kontekst njihove upotrebe (Rudgley 1995). U tom procesu sudjelovale su i životinje. Tradicionalne legende o svetim biljkama sadrže reference o životinjama koje su naučile ljude kako ih koristiti (Samorini 2002).

Korištenje psihoaktivnih sredstava seže tako daleko u prošlost starih, arhaičnih, ili urođeničkih kultura i naroda da su znanstvenici predložili hipotezu da su korijeni šamanizma i religije rezultat iskustava koje enteogeni izazivaju u ljudima u ritualima ograničenim na liječenje, magiju i/ili religiju (Grinspoon i Bakalar 1979; La Barre 1972; McKenna 1992; Schultes, Hofmann i Rätsch 2002; Smith 1964; Wasson i dr. 1986). Oni, čini se, ne samo da su ostavili tragove u formiranju šamanizma (La Barre 1972) nego se to znanje prenosilo svijetom kroz magiju, misterijske kultove i religije. ${ }^{6}$

${ }^{6}$ Taj prijenos znanja razmatraju brojni znanstvenici (Barker 2005; Dannaway 2010; Dannaway, Piper i Webster 2006; Grinspoon i Bakalar 1979; Merlin 2003; Rudgley 1995; Schultes, Hofmann i Rätsch 2002; Shanon 2002, 2008; Wasson 1972a, 1972b; Wasson i dr. 1986). Za ljudski doživljaj natprirodnog zaslužnija je, prema nekim znanstvenicima, kemijska i neurološka neravnoteža tijela izazvana infekcijskim bolestima i drugim nesrećama poput izgladnjivanja, iscrpljenosti ili dugih lovačkih ekspedicija (Smith 1988). Također, "tehnike poput posta, seksualne apstinencije, vježbi disanja, produljene budnosti i redovničke izolacije, korištene i na istoku i na zapadu, dizajnirane su da mijenjaju um procesom mijenjanja kemije tijela. Izmijenjena 
U tom kontekstu značajna su kretanja enteogena po svijetu poput ergota u misterijskim kultovima (Dannaway, Piper i Webster 2006) ili psihoaktivnih supstanci za paljenje i inhalaciju u kultovima tamjana, koji su se širili na putu tamjana. On je, kao i put svile, "kanal razmjene u starom svijetu koji je miješao jezike, religije, kulture i ideje sa svojim začinima i biljem. Povezivanje Egipta i Indije s rutom koja ide kroz Svetu zemlju vjerojatno je najstarija kontinuirana trgovačka ruta u povijesti” (Dannaway 2010: 488).

Najčešće su spominjani sljedeći enteogeni: soma u hinduizmu, haoma i konoplja u zoroastrijanizmu, pituri australskih Aboridžina, kykeon eleuzinskih misterija i vinova loza dionizijskih misterija u Grčkoj, benzoin u jugoistočnoj Aziji, čaj u zenu (Smith 1964), gljiva muhara u sibirskom šamanizmu, svete gljive teonanácatl, loza ololiuqiu i kaktus pejotl Azteka u Meksiku, alkohol šamanica u Koreji, ibogain u Africi (Partridge 2005a), ajahuaska u južnoameričkom šamanizmu, gljive u kršćanstvu, manna i shittim u židovstvu (Shannon 2002, 2008), te harmal u islamu (Dannaway 2010).

Enteogeni su često povezani s bogovima, interpretirani kao darovi bogova ili sami bogovi. Narkotik-bog soma u Indiji je diviniziran, meksičke gljive su Azteki zvali teonanácatl (božansko meso), pejotl se u Meksiku povezuje s bizonom (svetom životinjom) i kukuruzom (svetom vegetacijom), dok u Južnoj Americi ajahuaska znači vitica duše na kečuanskom jeziku (Schultes, Hofmann i Rätsch 2002). U staroj Europi, kykeon se povezuje s Demetrom (majkom zemlje, božicom žita, poljoprivrede i plodnosti) i njenom kćerkom Perzefonom (Grinspoon i Bakalar 1979; Wasson i dr. 1986) te vino s Dionizom ili Bakhom u grčko-rimskoj kulturi, bunika s Belom Kelta (bogom sunca, proroka i medicine), Thorom Germana i Jupiterom Rimljana (oba su povezana s gromom), konoplja s Freyjom Kelta i Germana (božicom ljubavi i senzualnosti), te opijum, bunika i muhara sa Odinom/Votanom Germana (iscjeliteljem, bijesnim, ekstatičkim). Njihova povezanost sa specifičnim bogom, mitom i ritualom indicira kako su te supstance promatrane u specifičnoj kulturi, za koga su dopuštene ili zabranjene, te za koga je njihovo korištenje dužnost (Godlaski 2011).

Međutim, ne koriste ih samo ovlašteni šamani, vračevi ili iscjelitelji nego i odrasla muška populacija, a manje žene, dok su za djecu uglavnom zabranjeni.? Njihova je upotreba najčešće ograničena na kontekst ceremonija (Schultes, Hofmann i Rätsch 2002) i kulta, a rijetko se spominju u smislu samotne individualne potrage ili zabave (Grinspoon i Bakalar 1979).

Ono što te rituale karakterizira je sljedeće. U tradicionalnim ritualnim kontekstima korištenja "neuobičajena iskustva inducirana enteogenima blisko su povezana s regulacijama općenitog načina provođenja života pojedinaca i društva” (Shanon 2002: 92). Enteogeni

stanja svijesti često se pojavljuju u trenucima krize, kada tijelo i um ne rade normalno" (Grinspoon i Bakalar 1979: 271).

Ipak, ima iznimki za djecu (brugmansia u Ekvadoru u ritualima povezanim s pubertetom) i žene (muhara u Sibiru, sveta gljiva u južnom Meksiku, ibogain u Africi). Zaboravljeni mogući razlog za isključivanje žena iz ritualnog gutanja enteogena je potencijal nekih halucinogena da izazovu pobačaj (Schultes, Hofmann i Rätsch 2002). 
u ritualu teže potvrditi autoritet svetih simbola i vjerovanja kulture, a i same su vizije često kulturno stereotipne (Grinspoon i Bakalar 1979). Drugim riječima, nije bitna sama enteogena biljka, već način na koji se upotrebljava, a uključuje rituale. Oni su oblikovani utvrđenim znanjem kulture, priznati i zasnovani na tradiciji, te nastoje održati društvo učeći pojedinca osnovna kulturna vjerovanja i vrijednosti, omogućavajući stvaranje identiteta pojedinca kao člana skupine i promovirajući grupnu koheziju (Barker 2005).

Čovjek je upoznat s oko 1000 enteogenih biljaka. U starom svijetu koristi ih se oko pedeset, a u novom približno sto trideset. Afrika ima malo enteogena, inuiti poznaju samo jednu psihoaktivnu biljku, a u Južnoj Americi, posebno u Meksiku, enteogeni su najprisutniji. Za tu situaciju nisu zaslužni samo botanički razlozi (Schultes, Hofmann i Rätsch 2002) nego i kulturni. Le Barre (1972) smatra da su Indijanci sačuvali šamanizam antičkih lovaca, kao i njihov temelj stvarnosti zasnovan na direktnom fizičkom iskustvu sila prirode. Oni su uz pomoć psihotropskih biljaka željeli osigurati jedinstvo s (nat)prirodnom okolinom, komunicirati s duhovima zaštitnicima, te inkorporirati natprirodne moći uz pomoć vizija šamana kao čuvara tradicije u lovu ili ratu. U prirodi te lovačko-sakupljačke kulture bilo je eksperimentiranje $s$ korištenim namirnicama što je pogodovalo lakšem pronalasku psihoaktivnih biljaka, a ne treba zaboraviti da su Indijanci došli iz iste regije kao i sibirska plemena i da su poznavali i koristili gljivu muharu. Dolaskom u novi svijet Indijanci su prenesenim šamanizmom stvorili jedan specifičan "narkotički kompleks". U starom svijetu, prema La Barreu (1972), na njihovu manje vidljivu kulturnu upotrebu utjecao je rast civilizacije, poljoprivrednog društva i svećeničke, monoteističke religije.

Treba primijetiti, također, prisutnost regulirajućih i restrikcijskih reakcija društva i institucija na upotrebu enteogena u takvim ritualima tijekom vremena.

U starom svijetu monoteističke religije imaju negativan odnos prema misticizmu i psihodeličnom iskustvu (Bakalar 1985; Clark 1970; Merlin 2003; Watts 1968). Primjerice, novoosnovano kršćansko Rimsko carstvo (27. - 1453.) u 4. stoljeću uvodi zabranu 2000 godina starih eleuzinskih misterija (Barker 2005: 180) i tijekom vremena dolazi do represije mističkog iskustva i proganjanja mističara poput Sokrata, Ivana Skota Eriugena, Majstora Eckharta i blažene Angele iz Foligna (Clark 1968, 1970; Watts 1968). To je doprinijelo zanemarivanju, zaboravu i odmaku od enteogena, a posebno psihodelika (Smith 1964).

U novom svijetu Maje su na Jukatanu u 14. stoljeću uvele restrikciju upotrebe gljive Psilociba mexicana na svećenstvo i plemstvo, kao i Inke za koku, a s vremenom je i zaboravljena upotreba nekih enteogena (gljiva teonanácatl, sjemenki oliliuqui) među Majama i Aztekima (Grinspoon i Bakalar 1979). Dolaskom europskih kolonizatora nastavlja se takva praksa, a kolonizacija "neciviliziranih" i "nazadnih" urođeničkih naroda legitimirala se željom za novim resursima i tržištima (Boyd 2001). Španjolski inkvizitori su 1620. godine zabranili narodu Huichol u Meksiku upotrebu pejotla u religijske svrhe, koja se od 1880. proširila u Sjevernu Ameriku, gdje su ga zabranile vlasti i kršćanski misionari (Sterling 1997).

U 19. stoljeću u Sjevernoj Americi primijenjena je legislativa kojom su regulirane i ograničene kulturne, političke i duhovne prakse urođeničkih naroda. Slično, u Južnoj Americi 
španjolski kolonizatori su u korištenju koke, pejotla, oliliuquia, yagea ili yopoa vidjeli izazov ranom kapitalizmu i kršćanskim interesima, demonizirali su upotrebu i sistematski primjenjivali nasilje. Katolička crkva htjela je koku staviti izvan zakona, no protivljenjem kolonizatora kultivacija koke postala je dio njihove ekonomije i crkvenih poreza (Boyd 2001: 79).

Isto tako, u Sjevernoj Americi prisutan je i kontekst industrijalizacije, socijalnih nemira i (katoličke) imigracije, koja je smatrana prijetnjom dominantnim protestantskim vrijednostima. Pokret umjerenosti, nastao u ranom 19. stoljeću, uz pojavu religijskih uvjerenja o samokontroli, moralnosti i apstinenciji, osnažen se usmjerio na kontrolu konzumacije alkohola (kasnije drugih droga) i devijantnosti, ali i rada. Dobili su potporu industrijalaca koji su smatrali da alkohol i drugi poroci otežavaju održavanje željene kapitalističke produktivnosti (Boyd 2001: 80-81). ${ }^{8}$

\section{SUVREMENI KONTEKST UPOTREBE ENTEOGENA}

U suvremenom svijetu opstale su "arhajske kulture povezane s drevnim tradicijama i načinom života" (Schultes, Hofmann i Rätsch 2002: 9) ili su se formirale sinkretističke religije koje ritualno koriste enteogene, preživjevši represiju do danas. Kult Bwiti koristio je ibogain u Gabonu, Kongu i Zairu9 (Furst 1976; Godlaski 2011; Grinspoon i Bakalar 1979; Schultes, Hofmann i Rätsch 2002), rastafarijanci kanabis na Jamajci i šire po svijetu (Dubreta i Perasović 1990; Hunt 2003; Partridge 2005a, 2005b; Perasović 2007), Crkva američkih domorodaca pejotl (Barker 2005; Clark 1968; Ott 1993; Partridge 2005a, 2005b; Schultes, Hofmann i Rätsch 2002; Sterling 1997) i skupina Chumash daturu (Barker 2005) u SAD-u, dok u Brazilu crkve Sainto Daime i União do Vegetal koriste ajahuasku (Barker 2005; Shannon 2002, 2008), a ta praksa i União do Vegetal se šire SAD-om, Europom i svijetom (Bullis 2008; Ott 1993; Tupper 2009).

Kult Bwiti i pejotl religija imaju oznake kulta krize i sinkretističke religije. To je pokušaj stvaranja osnove za jedinstvo "u kulturi koja je iskusila dezintegracijski utjecaj zapadne civilizacije" (Grinspoon i Bakalar 1979: 41). Zbog sličnih razloga (borbe protiv babilonskog rasizma, ${ }^{10}$ kolonijalizma i ropstva), rastafarijanizam počiva na crnačkom čitanju Biblije i kršćanstva, povezivanju sa starim Izraelcima, a apokaliptična i milenijalistička vjerovanja upućuju na oslobađanje i proročanstvo o dolasku Mesije, ras Tafariju (Haile Selassie)

\footnotetext{
${ }^{8}$ Razdoblje 19. stoljeća bilo je u pravnom smislu najpovoljnije za slobodno samoliječenje i eksperimentiranje srednjih i viših klasa s opijumom i hašišem (Boyd 2001; Partridge 2005a), što je uz otkrivanje i sintetiziranje droga krajem 19. i početkom 20. stoljeća pokazatelj utvrđene tradicije istraživanja njihovih svojstava (Grinspoon i Bakalar 1979).

${ }^{9}$ Zair je bio ime države od 1971. do 1997. godine, a nakon političke promjene njen novi naziv je Demokratska Republika Kongo.

${ }^{10}$ Babilon je za rastafarijance simbol tlačiteljskog bjelačkog društva, zakona i religije, a bjelački rasizam i diskriminacija vidljivi su u tim kontekstima, kao i kroz izloženost crnaca iskustvu kolonijalizma i ropstva na putovanju iz Afrike u novi svijet, što je utjecalo i na njihovo sjećanje, razmišljanje i djelovanje.
} 
i povratku u Etiopiju i Afriku (Dubreta i Perasović 1990; Hunt 2003; Partridge 2005a, 2005b; Perasović 2007).

U Sjevernoj Americi 1960-ih pojavljuju se psihodelične skupine The League for Spiritual Discovery, The Church of the Awakening (Clark 1968), The Church of the Tree of Life (Grinspoon i Bakalar 1979), kanabis duhovnosti u komunama poput Farme (Partridge 2005a, 2005b), a u 1980-im skupine koje koriste enteogene, primjerice The Assembly of the Church of Universe, Ethiopian Zion Coptic Church, The Religion of Jesus Church, The Children of the World Foundation i Temple of the True Inner Love (Partridge 2005a).

Moderni zapadni kontekst upotrebe psihoaktivnih supstanci, opisan u terminima ponešto manjkavog preporoda arhaičnih praksi (Rudgley 1995), sakralizacije psihodeličnih supstanci i psihodelične revolucije, povezan je s okultnom duhovnošću, održavanjem "odbačenog znanja" i umjetničkom aktivnosti (Partridge 2005a). Taj interes na zapadu dovodi se u vezu s romanticizmom, tradicijom mistike, zapadnjačkim ezotericizmom, duhovnošću i modernim preporodom interesa za religiju prirode (Partridge 2004). Taj se proces odvijao u tri faze.

Prva faza počinje 1938. kada Albert Hofmann u tvrtki Sandoz u Švicarskoj sintetizira LSD-25, a 1943. slučajno otkriva njegova psihoaktivna svojstva. Sandoz šalje uzorke istraživačkim institucijama i do 1960. objavljeno je više od petsto članaka o LSD-u, što se nastavilo do zabrane istraživanja na ljudima sredinom 1960-ih (Barusš 2003).

U Europi i SAD-u LSD i meskalin postali su obećavajući terapeutski alat za istraživanja uma (Grinspoon i Bakalar 1978). U Europi se profilirala psiholitička psihoterapija (dugotrajno korištenje malih doza kao pomoć oslobađanju i uvidu u nesvjesni materijal u psihoanalizi i psihoterapiji), a u Sjevernoj Americi psihodelična psihoterapija (kratkotrajno korištenje velikih doza kao put prema transcendentalnom, mističkom iskustvu i raspadanju obrana ega) (Barušs 2003; Dubreta 2005; Lerner i Lyves 2006; Walsh i Grob 2006). Tijekom 1950-ih i 60-ih provodila se terapija kroz drogom inducirano religijsko iskustvo (Osmondov i Hofferov eksperiment s alkoholičarima, Learyjeva rehabilitacija kriminalaca u zatvoru Concord, Kastovo korištenje LSD-a u tretiranju boli) i istraživana su mistička iskustva (Pahnkeov eksperiment u kapeli Marsh) (Clark 1968, 1970).

Timothy Leary i Richard Alpret (Ram Das) vodili su "Harvard psilocibin project" (1960. - 1962.), koji je doveo do eksperimenta sa zatvorenicima u zatvoru Concord i studentima teološkog seminara u kapeli Marsh (Partridge 2005a). Najznačajnije istraživanje mističkog potencijala napravio je Walter N. Pahnke pod Learyjevom paskom u kontroliranom eksperimentu tijekom službe u bostonskoj kapeli Marsh na Veliki petak 1962 godine. Studentima teološkog seminara dali su psilocibin (eksperimentalna skupina) i nikotin (kontrolna skupina). Rezultati su pokazali da unutar pravoga seta i settinga korištenje psihoaktivnih supstanci može dovesti do iskustva sličnog mističnom (Barušs 2003; Grinspoon i Bakalar 1979; Lerner i Lyves 2006; Roberts i Hruby 2002). Prema statističkim podacima, od četvrtine do trećine opće populacije imat će religijska iskustva prilikom uzimanja droga u prirodnim uvjetima; kod subjekata s izraženijom religijskom inklinacijom ta proporcija se 
penje do tri četvrtine, a ako se koristi u religijskom okruženju devet od deset ljudi ima takvo religijsko iskustvo (Smith 1964: 520).

Naglašen je njihov psihoterapeutski, psihijatrijski i mistički potencijal kroz javni rad Hoffmana, Osmonda, Hearda i Grofa s LSD-om (Partridge 2005a). Brojni izvještaji raspravljaju o utjecaju psihoaktivnih supstanci u tretiranju boli, alkoholičara i ovisnika o narkoticima, šizofrenih i psihotičnih stanja, oboljelih koji umiru od raka, te preživjelih zatočenika koncentracijskih logora (Walsh i Grob 2006). Istraživači, psihijatri, psiholozi i pacijenti naglašavali su pozitivna iskustva (Boyd 2001). I CIA je istraživala mogućnost njihove kontrole i njihov politički i ratni potencijal u manipulaciji i mentalnom slamanju protivnika, dok su popularizaciji psihodelika doprinijeli beatnici svojim zagovaranjem upotrebe droga i izazivanjem sustava (Boyd 2001; Dubreta 2005; Grinspoon i Bakalar 1979), Osmondov termin psihodelici (psychedelics) i Huxleyeva knjiga Vrata percepcije (Partridge 2005a, 2005b).

Druga masovnija, medijski i u popularnoj kulturi prisutnija faza traje od 1960-ih do 1970-ih. Leary, Allen Ginsberg i drugi akteri započinju psihodeličnu revoluciju u kojoj dolazi do povezivanja psihodelika i istočnjačke duhovnosti (hinduizma i budizma)." Uz slogan "turn on, tune in, and drop out" LSD je (uz marihuanu) postao važan element rastućeg kontrakulturnog pokreta (Partridge 2005a, 2005b). Kontrakulturna revolucija odvija se u kontekstu hladnog rata, nuklearne prijetnje i rata u Vijetnamu, te imigracije s istoka. Ona se ogleda u književnosti, ${ }^{12}$ glazbi, vizualnoj umjetnosti, kulturi mladih, mladenačkoj i studentskoj pobuni, te društvenoj kritici i otporu jednodimenzionalnom, tehnokratskom i alijeniranom društvu (Dubreta 2005; Grinspoon i Bakalar 1979; Krnić i Perasović 2013; Perasović 2001; Roszak 1969).

Moderna ritualna upotreba droga opisana je kao "slučajna, hedonistička, individualistička, psihički poremećena, uznemirujuća i kulturno dezintegrativna" (Grinspoon i Bakalar 1979: 54). Takve rituale oblikuju pojedinci ili manje skupine (supkulture), a društvo ih zabranjuje jer propituju uvriježene vrijednosti i vjerovanja i ne vode nužno grupnoj koheziji (Barker 2005). Ilegalnost i kaznene sankcije doprinijele su kriminalizaciji i osipanju pokreta. Psihodelični pokret bio je vrsta kriznog kulta nedovoljno asimilirane djece obilja i dokolice, a kako se raspad nastavio, njegovi su se dijelovi udaljili u različitim smjerovima (Grinspoon i Bakalar 1979).

Treća faza u 1980-im i 1990-im povezana je s pojavom elektronske glazbe i "plesnom" kulturom, odnosno supkulturama mladih koje nastavljaju kontinuitet s ranijim fazama (Boyd 2001; Dubreta 2005; Krnić i Perasović 2013; Partridge 2005a, 2005b; Perasović

\footnotetext{
${ }^{11}$ Širenje terminologije i učenja hinduizma i budizma u interpretacijama psihodeličnih iskustava povezano je s istočnjačkim istraživanjem mapa svijesti i uma koje su Zapadnjaci smještali u područje hereze i ludila te razočaranjem mladih u vlastitu kulturu (Bakalar 1985; Grinspoon i Bakalar 1979).

12 Mnogi poznati pisci koristili su psihodelike. Neka su njihova djela napisana pod utjecajem psihoaktivnih sredstava i sadrže percepciju društvene stvarnosti izmijenjenu njihovim djelovanjem (npr. Hunter S. Thompson: Strah i prezir u Las Vegasu, Ken Kesey: Let iznad kukavičjeg gnijezda, Jack Kerouac: Na cesti, William S. Burroughs: Goli ručak).
} 
2001). Prisutni su hedonizam i transcendencija. Okupljanja uz glazbu smatraju se novim svetim prostorima i ritualima, a muzika, ritam, ples i psihoaktivne supstance njihov su sastavni dio.

Od 1990-ih u SAD-u se ponovno istražuju psihodelici pod dopuštenjem vlade (Barušs 2005). Raste broj publikacija, mreža, organizacija i online resursa o enteogenima (Partridge 2005a: 124-126; Roberts i Hruby 2002: 72; Walsh i Grob 2005: 261). Podržavajuća istraživačka klima rezultat je širenja intelektualnog konteksta prihvaćanja paradigme višestrukih psihofizičkih stanja, razvoja psihologije koji je omogućio da ona istražuje sva psihofizička stanja i načine njihovog dostizanja, te širenja religijskog priznavanja značaja primarnog religijskog iskustva (Roberts i Hruby 1996, 2002). Ona je utjecala na ponovni znanstveni interes za istraživanje mističkih i duhovnih iskustava (Godlaski 2011).

Primjerice, rezultati istraživanja Lernera i Lyvesa (2006) o vrijednostima i vjerovanjima korisnika droga u skladu su s prethodnim nalazima Pahnkea i Doblina o dubokom duhovnom utjecaju psihodeličnog iskustva. Oni ističu značaj faktora prije korištenja droga i psihodelične posljedice. Uspoređivali su vrijednosti, vjerovanja, mogućnost suočavanja sa stresom i empatiju izraelskih i australskih korisnika psihodeličnih droga, korisnika ostalih ilegalnih droga i onih koji nisu korisnici. Bez obzira na kulturno porijeklo, korisnici psihodeličnih droga statistički značajno više izražavaju mistična vjerovanja (jedinstvo s bogom i svemirom, iluzorna priroda fizičke egzistencije, prisustvo transcendentalne realnosti) od ostale dvije skupine; emocionalna empatija izraženija je kod njih nego kod ostale dvije skupine, ali je značajnija samo od onih koji ne koriste ilegalne droge; oni također značajno više vrednuju neke životne vrijednosti (duhovnost i briga za druge) od ostale dvije skupine, brigu za okoliš i kreativnost izražavali su značajnije od korisnika ostalih ilegalnih droga, dok su financijski prosperitet isticali značajno manje od ostale dvije skupine; kod sposobnosti suočavanja sa stresom, korisnici ostalih droga (marihuane, amfetamina) imaju značajno niže rezultate u odnosu na ostale dvije skupine.

Istovremeno, od kraja druge faze u Sjevernoj Americi započinje "rat protiv droga" kao "kulturni rat" koji naglašava "očuvanje judeo-kršćanskih vrijednosti" (Sterling 1997: 168), ali stvara i veliki dio problema ovisnosti (Weil i Rosen 1983: 16). Kritiku takvog odnosa institucija prema drogama, kao zločina prema prirodi (ljudi i životinja), kroz znanstvenu, praktičnu ili pravnu, moralnu i ekonomsku perspektivu nudi Ott (1993). To je bio politički odgovor na gubitak državne i korporativne kontrole tijekom 1960-ih. Mnoge zajednice postale su "ratne zone" (negativne posljedice i ovisnička kvaliteta specifičnih droga su najizraženije) u tom ratu, čiji su rezultati ugroza ljudskih prava i sloboda, znatno povećanje zatvorske populacije (većinom siromašni, manjine, crnci i žene) i rast zatvorske industrije, koja je postala ozbiljan poslovni pothvat. Negativna ovisnost (destruktivna ponašanja) nije "problem droge", već destruktivnog globalnog kapitalizma i društvenog odgovora na prolongiranu dislokaciju "u društvima u kojima su globalne tržišne snage, kontinuirana kolonizacija i alijenacija uništile tradicionalne kulture, ekonomije i društvene odnose, uz dislokaciju pojedinaca i skupina" (Boyd 2001: 90). 
Javlja se pitanje slobode vjere i uvjerenja te odvojenosti crkve i države u odgovornom korištenju enteogena u ritualima (Bullis 2008; Grinspoon i Bakalar 1979; Roberts i Hruby 1996, 2002; Sterling 1997; Watts 1968). Godine 1990. Vrhovni sud SAD-a je u slučaju religijske upotrebe pejotla u Crkvi američkih domorodaca presudio da ona nije zaštićena Prvim amandmanom Ustava. Religijski vođe stvorili su Koaliciju za slobodnu upotrebu religije i uvjerili Kongres da poništi slučaj, da 1993. godine donese Zakon o obnovi religijskih sloboda koji joj daje pravo korištenja pejotla, te prizna da korištenje pejotla u ritualnom okruženju nije štetno (Sterling 1997).

Godine 2006. Vrhovni sud SAD-a dozvolio je ritualnu upotrebu ajahuaske crkvi União do Vegetal. Ta odluka potvrđuje ulogu Zakona o obnovi religijskih sloboda u izuzimanju korištenja enteogena, ali je stvorila i presedan za širenje korištenja enteogena na nove supstance i kulturne skupine, uz naglašavanje nedostatka empirijskih dokaza o štetnim posljedicama ajahuaske na sakralne korisnike. Religijska skupina će najvjerojatnije primiti takvo izuzimanje ako može pokazati 1) da je religija, 2) s jakim i dokazivim zapisom upotrebe enteogena, 3) da je njihova upotreba religijska obaveza, 4) da ima nizak rizik diverzije i 5) da ima nisku razinu štetnosti povezanu sa sakramentalnom upotrebom (Bullis 2008).

\section{ZAKLJUČAK}

Istraživanja su pokazala da dio ljudske populacije barem zadnjih 10000 godina u svojim kulturama i društvima izražava potrebu izmjene stanja svijesti i korištenja psihoaktivnih sredstava kako bi interpretirao svoju unutarnju i vanjsku okolinu i utjecao na nju određenim djelovanjem. Čini se da je potreba za povremenom promjenom stanja svijesti dio ljudske prirode, prisutna je u različitim kulturama, razdobljima i prostorima, te je intrinzično povezana s potragom za transcendencijom. Postoji više različitih načina na koje se ona mogu doseći, a jedan od njih je upotreba psihoaktivnih sredstava. Njihovo poznavanje i upotreba u kulturama su gotovo univerzalne pojave, a s njima su povezane i životinje.

Razlike u broju poznatih i korištenih enteogenih biljaka i pripravaka između starog (veći broj) i novog (manji broj) svijeta imaju svoje botaničke, ali i kulturne razloge. Oni su doveli do toga da je u starom svijetu manje vidljiva njihova kulturna upotreba, da je brže zabranjena i zaboravljena zbog rasta civilizacije, poljoprivrednog društva i svećeničke, monoteističke religije, te progona mističara i psihodeličnog iskustva, dok su Indijanci prenesenim šamanizmom stvorili jedan specifičan "narkotički kompleks” širenja tog znanja, koji je opstao čak i nakon zabrana koje su uvedene kod Maja i Inka, a kasnije kolonizacijom, migracijom, industrijalizacijom i pojavom pokreta umjerenosti.

Ljudi su enteogene povezivali sa svetim, sa specifičnim bogom, mitom i ritualom, koristili su ih mahom u okviru rituala i kulta, a rjeđe individualno i radi zabave, a osim šamana, vračeva i iscjelitelja koristila ih je većinom odrasla muška populacija, a manje žene i djeca. Oni su našli svoje mjesto i bili korišteni u šamanizmu, magiji, iscjeljenju, umjetnosti, 
misterijskim kultovima i religijama poput eleuzinskih i dionizijskih misterija. Takvi su rituali potvrđivali simbole, vjerovanja i vrijednosti kulture, a služili su i društvenoj integraciji.

Unatoč protoku vremena i zabranama, enteogeni se i danas koriste na sličan način, jer su opstale arhajske kulture i pojavile su se sinkretističke religije (s oznakama kulta krize) poput kulta Bwiti, rastafarijanaca, Crkve američkih domorodaca, crkvi Sainto Daime i União do Vegetal, te psihodelične skupine koje ih koriste u ritualima. Istražuje se njihov psihoterapijski, psihijatrijski i mistični potencijal, a uočljivo je i suvremeno medijski i javno naglašenije subverzivno, rekreativno i hedonističko korištenje kod beatnika, kontrakulturnog pokreta i plesnih (sub)kultura mladih. To se dešava u uvjetima zakonske zabrane, kriminalizacije, ilegalnosti i idiosinkratičnosti njihove upotrebe, koja se percipira kao društveno opasna i dezintegrativna. Prisutni su i problemi zabrana, ovisnosti, rata protiv droga, te kršenja ljudskih i vjerskih prava i sloboda.

Sve navedeno su primjeri korištenja psihoaktivnih sredstava u ritualu, u religijskim i društvenim inicijacijama i obredima prijelaza, ali i u znanstvenim istraživanjima njihovog terapijskog i mističnog potencijala. S obzirom na kontekst njihove upotrebe oni se mogu promatrati kao društveno integrativni ili društveno dezintegrativni. Rezultat tog društvenog procesa uvelike ovisi o stavu i reakcijama kulture, društva i njegovih institucija te u velikoj mjeri određuje sudbinu njihovog korištenja, kao i samih korisnika.

U društveno-humanističkom razmatranju upotrebe enteogena u ritualnim kontekstima bilo bi zanimljivo istražiti vremensku podudarnost i sinkronicitet pojavljivanja psihodelika i bricolage ili eklektične religioznosti i duhovnosti novih religijskih pokreta, ekološkog pokreta i duhovnosti zasnovane na zemlji na zapadu, kao i njihove međusobne isprepletenosti, za što postoje naznake u literaturi, ali zbog ograničenog opsega ovoga rada nije bilo mogućnosti za takva izlaganja.

Suvremeni društveni odgovori i posljedice negativnog i restriktivnog pristupa takvim iskustvima kao manje vrijednima rezultiraju velikim društvenim troškovima, a zanemaruje se njihov naznačeni potencijal. Prema nekim tipovima psihodeličnog iskustva i njihovim karakteristikama, kao i istraživanjima mističkog iskustva, upotreba psihodeličnih sredstava (enteogena) mijenja vrijednosti i vjerovanja njihovih korisnika, a neka od njih predstavljaju i prijetnju kapitalističkom sustavu (Boyd 2001).

Istraživanja toga polja donose spoznaje koje mogu biti relevantne za razna tematska područja poput religije, duhovnosti, novih religijskih i društvenih pokreta, ali i znanosti i (psihičkog) zdravlja. U tom smislu, postavlja se pitanje nije li korištenje enteogena jedan od relevantnih načina refleksije čovjeka na probleme i promjene koji nastaju u njegovom životu ili u životu šireg društva i kulture, čak i kada se obračunava s nekim njenim vrijednostima i normama? Nije li i devijantno ponašanje ponekad pozitivno, jer može biti katalizator promjene i upozoriti na neki društveni problem i nužnost promjene?

Kakvo god pitanje postavili i kakav god odgovor dali na upotrebu psihoaktivnih sredstava u ritualu, Grinspoon i Bakalar (1979) smatraju da možemo naučiti nešto od tradicionalnih 
religijskih oblika korištenja droga, posebice o prirodi našeg svijeta, zaštitničkoj i asimilacijskoj funkciji rituala te balansu između demokracije i autoriteta u regulaciji upotrebe psihodeličnih droga, kao i bilo kojeg drugog oblika ljudskog djelovanja.

\section{NAVEDENA LITERATURA I IZVORI}

Aaronson, Bernard i Humphry Osmond. 1970. Psychodelics. The Uses and Implications of Hallucinogenic Drugs. New York: Doubleday.

Abercrombie, Nicholas, Stephen Hill i Bryan S. Turner, ur. 2008. Rječnik sociologije. Zagreb: Jesenski i Turk.

Bakalar, James B. 1985. "Social and Intellectual Attitudes Toward Drug-Induced Religious Experience". Journal of Humanistic Psychology 25/4: 45-65. [https://doi.org/10.1177/0022167885254008]

Barker, John R. 2005. "Psychedelic Sacraments”. Journal of Psychoactive Drugs 37/2: 179-187. [https:// doi.org/10.1080/02791072.2005.10399799]

Barušs, Imants. 2003. Alterations of Consciousness. An Empirical Analysis for Social Scientists. Washington, DC: American Psychological Association. [https://doi.org/10.1037/10562-000]

Boyd, Susan. 2001. "The Regulation of Altered States of Counsciousness. A History of Repression and Resistence". Contemporary Justice Review 4/1: 75-100.

Bullis, Ronald K. 2008. "The "Vine of the Soul" vs. the Controlled Substances Act. Implications of the Hoasca case". Journal of Pschoactive Drugs 40/2: 193-199. [https://doi.org/10.1080/02791072. 2008.10400630]

Castaneda, Carlos. 1979. The Teachings of Don Juan. A Yaqui Way of Knowledge. Harmondsworth: Penguin Books.

Clark, Walter H. 1968. "Religious Aspects of Psychedelic Drugs". California Law Review 56/1: 86-99. [https://doi.org/10.2307/3479498]

Clark, Walter H. 1970. "The Psychodelics and Religion". U Psychodelics. The Uses and Implications of Hallucinogenic Drugs. Bernard Aaronson i Humphry Osmond, ur. New York: Doubleday, 182-195.

Dannaway, Frederick R. 2010. "Strange Fires, Weird Smokes and Psychoactive Combustibles. Entheogens and Incense in Ancient Traditions". Journal of Psychoactive Drugs 42/4: 485-497. [https:// doi.org/10.1080/02791072.2010.10400711]

Dannaway, Frederick R., Alan Piper i Peter Webster. 2006. "Bread of Heaven or Wines of Light. Entheogenic Legacies and Esoteric Cosmologies". Journal of Psychoactive Drugs 38/4: 493-503. [https:// doi.org/10.1080/02791072.2006.10400588]

Dubreta, Nikša. 2005. Društvo i odnos prema drogama. Sociokulturni kontekst upotrebe kanabisa. Zagreb: Hrvatska sveučilišna naklada.

Dubreta, Nikša i Benjamin Perasović. 1990. “Rastafarijanska utopija”. Revija za sociologiju 21/4: 671-680.

Elijade, Mirča. 1990. Šamanizam i arhajske tehnike ekstaze. Sremski Karlovci: Izdavačka knjižarnica Zorana Stojanovića.

Forte, Robert, ur. 1997. Entheogens and the Future of Religion. San Francisco: Council on Spiritual Practices.

Furst, Peter T. 1972. Flesh of the Gods. The Ritual Use of Hallucinogens. New York: Praeger.

Furst, Peter T. 1976. Hallucinogens and Culture. San Francisco: Chandler \& Sharp Publishers.

Godlaski, Theodore M. 2011. “Gods of Drugs. The God Within”. Substance Use \& Misuse 46: 1217-1222. [https://doi.org/10.3109/10826084.2011.561722] 
Grakalić, Marijan M. 1994. Duhovnost novog doba. Historiozofska monografija. Zagreb: Arkadia.

Grinspoon, Lester i James B. Bakalar. 1979. Psychedelic Drugs Reconsidered. New York: Basic Books.

Hunt, Stephen J. 2003. Alternative Religions. A Sociological Introduction. Aldershot: Ashgate.

Iolar. 2013. "Obredi prijelaza". Dostupno na: http://www.zarez.hr/clanci/obredi-prijelaza (pristup 4. 11. 2017.).

“I Crkva i HDZ će izopćiti šamana Luku Hodaka”. 2009. Jutarnji.hr. Dostupno na: http://www.jutarnji.hr/ arhiva/i-crkva-i-hdz-ce-izopciti-samana-luku-hodaka/3811380/(pristup 4. 11. 2017.).

Keller, Ivana. 2010. Etnobotaničke značajke nekih biljnih vrsta. Završni rad. Križevci: Visoko gospodarsko učilište u Križevcima.

Krnić, Rašeljka i Benjamin Perasović. 2013. Sociologija i party scena. Zagreb: Naklada Ljevak.

La Barre, Weston. 1972. "Hallucinogens and the Shamanic Origin of Religion". U Flesh of the Gods. The Ritual Use of Hallucinogens. Peter T. Furst, ur. London: George Allen \& Unwin Ltd., 261-278.

Lerner, Michael i Michael Lyvers. 2006. "Values and Beliefs of Psychedelic Drug Users. A Cross-Cultural Study". Journal of Psychoactive Drugs 38/2: 143- 147.

Lyttle, Thomas. 1999. Psychedelics Reimagined. New York: Autonomedia.

Ma., D. 2009. “HDZ me želi eliminirati prije drugog kruga izbora”. Dostupno na: https://dnevnik.hr/vijesti/ lokalni-izbori/hodak-tvrdi-da-ga-je-fizicki-napao-lokalni-hdz-ovac.html (pristup 4. 11. 2017.).

Merlin, Mark D. 2003. "Archaeological Evidence for the Tradition of Psychoactive Plant Use in the Old World". Economic Botany57/3:295-323. [https://doi.org/10.1663/0013-0001(2003)057[0295:AEFTTO]2.0.CO;2]

Milićević Bradač, Marina. 2002. “Vučedolska ‘golubica' kao posuda”. Opuscula Archaeologica 26: 71-98.

McKenna, Terence. 1992. Food of the Gods. The Search for the Original Tree of Knowledge. New York: Bantam.

Ott, Jonathan. 1993. Pharmacotheon. Entheogenic Drugs, Their Plant Sources and History. Kennewick, WA: Natural Products Co.

Pahnke, Walter N. 1967. "LSD and Religious Experience". U LSD, Man E Society. Richard C. DeBold i Russell C. Leaf, ur. Middletown, Connecticut: Wesleyan University Press. Dostupno na: http://www. druglibrary.org/schaffer/lsd/pahnke3.htm (pristup 14. 1. 2014.).

Partridge, Christopher. 2004. The Re-Enchantment of the West, 1. Alternative Spiritualities, Sacralization, Popular Culture, and Occulture. London: T\&T Clark.

Partridge, Christopher. 2005a. The Re-Enchantment of the West, 2. Alternative Spiritualities, Sacralization, Popular Culture, and Occulture. London: T\&T Clark.

Partridge, Christopher, ur. 2005b. Enciklopedija novih religija. Nove religijske sekte i alternativni duhovni pokreti. Naklada Ljevak: Zagreb.

Perasović, Benjamin. 2001. Urbana plemena. Sociologija supkultura u Hrvatskoj. Zagreb: Hrvatska sveučilišna naklada.

Perasović, Benjamin. 2007. “Rastafarijanstvo u Hrvatskoj”. Sociologija i prostor 45/3-4: 301-320.

Plečko, Drago. 1997. Droge. Bič novog doba. Samobor: K-2.

Rebić, Adalbert, ur. 2002. Opći religijski leksikon. Zagreb: Leksikografski zavod Miroslav Krleža.

Roberts, Thomas B., ur. 2001. Psychoactive Sacramentals. Essays on Entheogens and Religion. San Francisco: Council on Spiritual Practices.

Roberts, Thomas B. i Paula J. Hruby. 1996. "Entheogens - Return of the Ostracized". Rad predstavljen na The Annual Meeting of the American Educational Research Association, New York, NY, 8. - 12. 4. 1996. 
Roberts, Thomas B. i Paula J. Hruby. 2002. "Towards an Entheogen Research Agenda”. Journal of Humanistic Psychology 42/1: 71-89. [https://doi.org/10.1177/0022167802421004]

Roszak, Theodore. 1969. The Making of a Counter Culture. New York: Anchor Books.

Roško, Zoran. 2005. "Psihodelija”. Zarez 7/166: 20-29.

Ruck, Carl A. P., Jeremy Bigwood, Danny Staples, Jonathan Ott i Gordon Wasson. 1979. "Entheogens". The Journal of Psychedelic Drugs 11/1-2: 145-146. [https://doi.org/10.1080/02791072.1979.104 72098]

Rudgley, Richard. 1995. "The Archaic Use of Hallucinogens in Europe. An Archaeology of Altered States". Addiction 90: 163-164. [https://doi.org/10.1111/j.1360-0443.1995.tb01023.x]

Samorini, Giorgio. 2002. Animals and Psychedelics. The Natural World and the Instinct to Alter Consciousness. Roachester: Park Street Press.

Schultes, Richard E., Albert Hofmann i Christian Rätsch. 2002. Plants of the Gods. Their Sacred, Healing and Hallucinogenic Powers. (2nd revised ed.). Vermont: Healing Arts Press.

Shanon, Benny. 2002. "Entheogens. Reflection on 'Psychoactive Sacramentals". Journal of Consciousness Studies 9/4: 85-94.

Shanon, Benny. 2008. "Biblical Entheogens. A Speculative Hypothesis". Time and Mind. The Journal of Archaeology Consciousness and Culture 1/1:51-74. [https://doi.org/10.2752/175169608783489116]

Smith, Huston. 1964. “Do Drugs Have Religious Import?”. The Journal of Philosophy 61/18: 517-530.

Smith, Huston. 1988. "Psychedelics and Religion. An Addendum". ReVision. Journal of Consciousness and Change 11/1: 35-37.

Sterling, Eric E. 1997. “Law Enforcement against Entheogens. Is it Religious Persecution?”. U Entheogens and the Future of Religion. Robert Forte, ur. San Francisco: Council on Spiritual Practices, 165-172.

"Luka Hodak u Saborskom porazio HDZ". 2009. Tportal.hr. Dostupno na: https://www.tportal.hr/vijesti/ clanak/luka-hodak-u-saborskom-porazio-hdz-20090518/print (pristup 4. 11. 2017.).

Tupper, Kenneth W. 2009. "Ayahuasca Healing Beyond the Amazon. The Globalization of a Traditional Indigenous Entheogenic Practice". Global Networks 9/1: 117-136. [https://doi.org/10.1111/j.14710374.2009.00245.x]

Tuškan, Danijel 2010. "HDZ-ov šaman Hodak je kriv za smrt susjeda, ali ne ide u zatvor". Dostupno na: http://www.jutarnji.hr/vijesti/hrvatska/hdz-ov-saman-hodak-je-kriv-za-smrt-susjeda-ali-ne-ide-uzatvor/1890414/ (pristup 4. 11. 2017.).

Walsh, Roger i Charles S. Grob. 2005. Higher Wisdom. Eminent Elders Explore the Continuing Impact of Psychedelics. Albany: State University of New York Press.

Walsh, Roger i Charles S. Grob. 2006. "Early Psychedelic Investigators Reflect on the Psychological and Social Implications of their Research". Journal of Humanistic Psychology 46/4: 432-448.

Wasson, R. Gordon. 1972a. "The Divine Mushroom of Immortality". U Flesh of the Gods. The Ritual Use of Hallucinogens. Peter T. Furst, ur. New York: Praeger, 185-200.

Wasson, R. Gordon. 1972b. "What Was the Soma of the Aryans?". U Flesh of the Gods. The Ritual Use of Hallucinogens. Peter T. Furst, ur. New York: Praeger, 201-213.

Wasson, R. Gordon, Stella Kramrisch, Jonathan Ott i Carl A. P. Ruck. 1986. Persephone's Quest. Entheogens and the Origins of Religion. New Haven: Yale University Press.

Watts, Alan. 1968. "Psychedelics and Religious Experience". California Law Review 56/1: 74-85. [https:// doi.org/10.2307/3479497]

Weil, Andrew i Winifred Rosen. 1983. From Chocolate to Morphine. Everything You Need to Know About Mind-altering Drugs. Boston: Houghton Mifflin Co. 


\section{ENTHEOGENS: PSYCHOACTIVE INGREDIENTS OF SOME RITUALS AND THEIR DESTINY}

This article deals with the use of psychoactive substances in rituals. In addition to tackling the issue of defining drugs and related terms (psychedelics, hallucinogens, entheogens), the article presents maps of altered states of consciousness related to their use, as well as types of psychedelic experience and factors affecting them, concepts of religion/faith and rituals that define the conceptual framework, and shows that the phenomenon has not been treated adequately in the Croatian context. The article considers the historical and contemporary context of their use in medicine, shamanism, magic, religion, as well as in spirituality, art, psychiatry, psychotherapy, counterculture and youth subculture. Moreover, the discussion presents the geography, botanical and cultural scope of entheogen usage, as well as the similarities and differences in psychoactive substance use and in the responses of social institutions. Some of the social problems and consequences that the regulation of their use presents to the modern society are highlighted, including restrictive legislation, the "war on drugs", preventing scientific research of the phenomenon, as well as violations of human rights and religious freedoms. The article concludes by emphasizing the research potential of the topic and the challenges it presents.

Keywords: entheogens, psychoactive substances, religion, spirituality, counterculture, subculture, ritual, social regulation 